\title{
The provenance of erratic pebbles from a till in the vicinity of the city of Radom, central Poland
}

\author{
Piotr Jan Strzelecki \\ AGH University of Science and Technology, Faculty of Geology, Geophysics and Environmental Protection, Department of \\ Fossil Fuels; al. A. Mickiewicza 30, 30-059 Krakow, Poland; e-mail:piotrjanstrzelecki@gmail.com
} (C) 2019 Authors. This is an open access publication, which can be used, distributed and reproduced in any medium according
to the Creative Commons CC-BY 4.0 License requiring that the original work has been properly cited.

Received: 11 November 2018; accepted: 18 January 2019; first published online: 15 February 2019

\begin{abstract}
Petrographic analysis, including the indicator erratics count method of coarse pebbles (20-60 mm), was performed for the first subsurface layer of the glacial till in the vicinity of the city of Radom. Crystalline rocks comprise $60 \%$ of the sample, whereas carbonate and clastic sedimentary rocks total $18 \%$ and $15 \%$, respectively. Among the crystalline rocks, $14 \%$ clasts were identified as indicator erratics. The majority of the indictor erratics originated from the Åland region (63\%). Significant contributions were also derived from the central Baltic Basin (12\%), Ångermanland (9\%) and Uppland (9\%) regions. Trace amounts are recorded from the northern Baltic, Dalarna and Småland regions. The spatial distribution of crystalline erratic source areas suggests material incorporation into an ice sheet mainly from central-eastern Fennoscandia. The indicator assemblage composition indicates the Odranian (MIS 6) origin of the till. The majority of the erratic sedimentary rocks were derived from the central and southern Baltic Basin while local rocks comprise a minor proportion. The relatively low carbonate clasts content indicates that the till was affected by partial decalcification resulting from post-depositional chemical weathering. This study supplements the results on erratic pebble provenance in the glacial tills of Middle Polish Glaciation Complex in Poland.
\end{abstract}

Keywords: Pleistocene, MIS 6, indicator erratics, till, central Poland

\section{INTRODUCTION}

The vast majority of Poland's territory was covered by ice sheets over the course of multiple Pleistocene glaciations. The relics of these events are well preserved, especially in the Polish Lowlands, in the form of glacial landforms. Apart from these mesoscale features, erratic boulders are also commonly encountered. These rocks of "exotic" origin, usually transported distances of over several hundred kilometres from their source area by an ice sheet, have been assigned geotouristic value and constitute monuments (e.g. Czubla \& Mizerski 2003, Górska-Zabielska 2017). This is not only due to their size, but also their mineral composition, structure and texture. Much more abundant among glacial sediments, the smaller counterparts of the boulders i.e. pebbles, still have a legible record of these features. These properties are of special interest at the scientific level since they allow the assignment of erratics to their source areas and, as a result, indicators have been distinguished among them (Milthers 1909). These play the most important role as they have characteristic petrographic features that allow for their unequivocal identification with a well-defined, relatively small origin area (e.g. Korn 1927, Hesemann 1936, 1975, Lüttig 1958, Smed 1989, Zandstra 1999, Czubla et al. 2006). Beside these indictors, auxiliary erratics were distinguished (Czubla 
2015b). These erratics have large source areas and are mainly sedimentary in origin. Taking into account the possibility of the collection of a statistically significant number of specimens from one site, it makes erratic pebbles analysis an attractive tool for till investigation. This finds confirmation in its common application in studies on Pleistocene continental glaciations in Poland (e.g. Czubla 2001, 2015b, Gałązka 2004, Górska-Zabielska 2008 and references therein) and Europe (e.g. Hesemann 1931, Hoffmann \& Meyer 1999, Zandstra 1999, Hanáček \& Nývlt 2009, Smed 2010 and references therein). Recent studies show that a regional knowledge of indicator erratic assemblages could be successfully used for stratigraphic position determination (Czubla 2015b, Czubla et al. 2017). Therefore, continuous data enrichment by new studied sites is both justified and needed for a better understanding of the regional distribution of erratic clasts to reveal the characteristics of previous glaciations.

The main aim of the study is to reveal the provenance of erratic pebbles $(20-60 \mathrm{~mm})$ using the indicator erratics count method. In addition, it intends to confront the stratigraphic position of the subsurface till in the vicinity of the city of Radom, based on the correlation of results with regional data from Polish territory. The study presents the first results on the provenance of erratic pebbles in the study area.

\section{REGIONAL SETTING}

The study area is situated in central Poland, ca. $60 \mathrm{~km}$ to the north of the Holy Cross Mountains, in the central part of the Radom Plain (Kondracki 1998). The regional landscape consists of gently undulating glacial landforms of till plain and hills, which are cut by minor, flat or gently sloping valleys (Jaśkowski et al. 2014). Human activity and thin soil layer often favours the exposure of shallow geological layers.

The bedrocks for Quaternary sediments constitute Paleogene and Cretaceous strata (Jaśkowski et al. 1993). Cretaceous bedrock is composed of limestone, shaly limestone, marl and sandy limestone, whereas the Paleogene bedrock is comprised of sand and mud with glauconite. Quaternary strata comprise almost exclusively glacial sediments. The origin of the oldest sediments, which were recognised only in drillings are related to South Polish Glaciation Complex (Jaśkowski et al. 2014). It is likely that they were preserved only locally in bedrock depressions. Most of the area is covered by glacial sediments of the Middle Polish Glaciation Complex (Middle Pleistocene). They include tills and glaciofluvial sand and gravel units. Locally, they are overlain by aeolian sand (Fig. 1). The youngest strata filling the valleys and depressions are Holocene mud, sand and sand with gravel. The Quaternary cover is up to 30 meters thick (Jaśkowski et al. 1993).

The studied region is localised within the area covered by ice sheets of the South and Middle Polish Glaciation Complexes. All of the glaciations of the South Polish Glaciation Complex covered entirely the area, reaching the foreland of the Carpathians, in contrast to the younger glaciations of the Middle Polish Glaciation Complex (Marks et al. 2016). The studied site is localised in the zone of the maximum extent of several glaciations from the Middle Polish Glaciation Complex. Hence, ambiguities on the age of glacial sediments and therefore the extent of the particular glaciations of the Middle Polish Glaciation Complex in the study area has been the object of the debate in recent decades (cf. Kowalski \& Jaśkowski 1998, Lindner 2005). The current division of the Middle Polish Glaciation Complex distinguishes three glaciations (Fig. 2): the Liwiecian, Krznanian and Odranian (Marks et al. 2016). According to this division, only two glaciations covered the study area (Fig. 3). The previous division of the Middle Polish Glaciation Complex comprised the Liwiecian, Odranian and Wartanian Glaciations (e.g. Marks 2005). However, the findings of Lindner (2005) in the adjacent areas to the studied region contributed to the redefinition of the Middle Polish Glaciation Complex stratigraphy and naming (cf. Ber et al. 2007). The Odranian Glaciation, assigned to marine isotope stage (MIS) 8 was concluded to be younger than previously considered and assigned to the Wartanian Glaciation (MIS 6). The Wartanian Glaciation now has the rank of post-maximum stadial (Marks et al. 2016). In light of recent data, only the Krznanian (MIS 8) and Odranian (MIS 6) glacial sediments are present in the study region. 


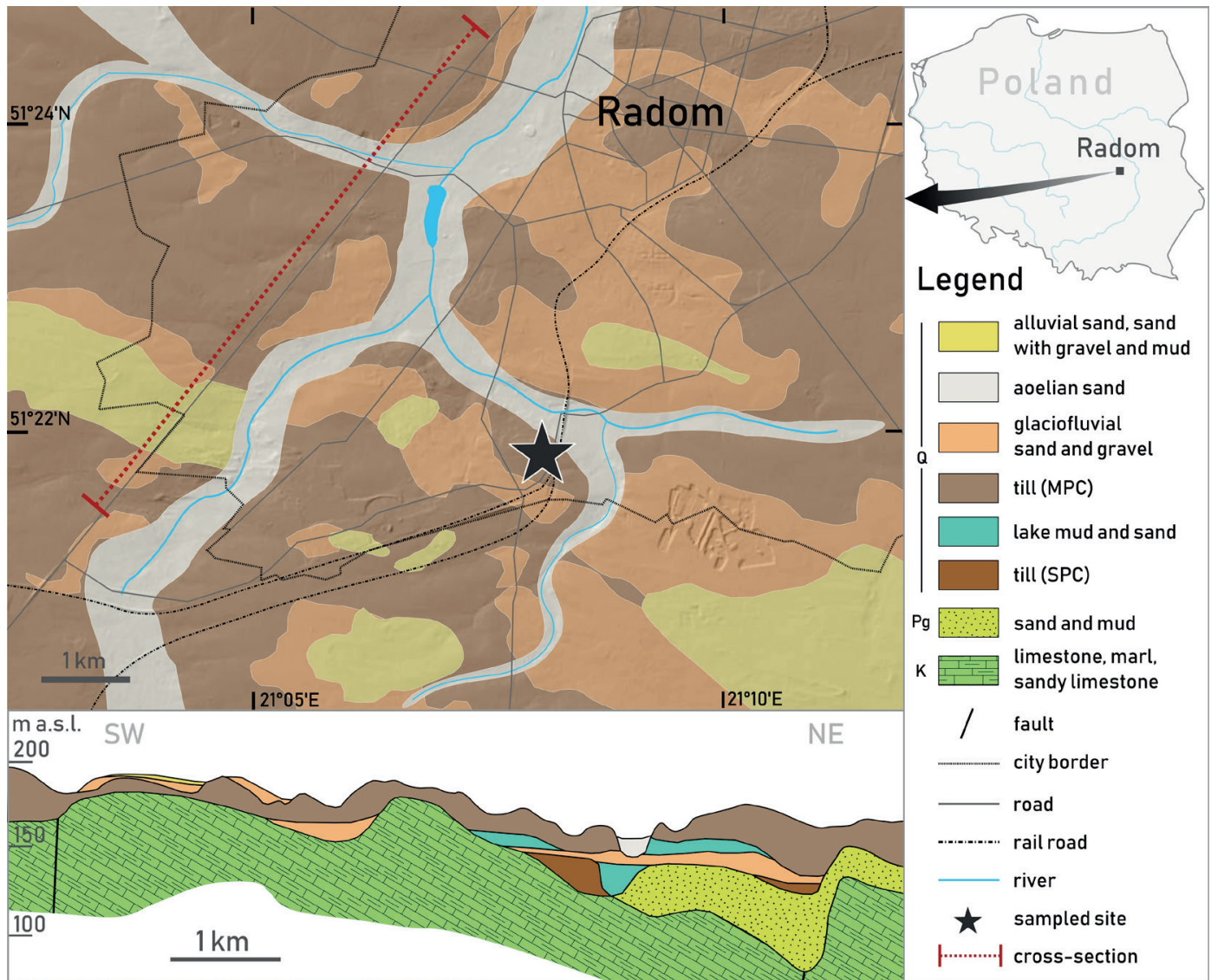

Fig. 1. Simplified geological map and cross-section of the Radom area (after Jaśkowski et al. 1993): Q - Quaternary, Pg - Paleogene, K - Cretaceous, MPC - Middle Polish Glaciation Complex, SPC - South Polish Glaciation Complex

\begin{tabular}{|c|c|c|c|c|}
\hline \begin{tabular}{|c|} 
age \\
ka BP
\end{tabular} & stratigraphy & complexes & $\begin{array}{l}\text { glaciations } \\
\text { interglacials }\end{array}$ & MIS \\
\hline 117 & \multicolumn{3}{|c|}{ Holocene } & \\
\hline \multirow[b]{2}{*}{130} & \multirow{2}{*}{$\begin{array}{c}\text { Upper } \\
\text { Pleistocene }\end{array}$} & \multirow{2}{*}{$\begin{array}{l}\text { North } \\
\text { Polish }\end{array}$} & Vistulian & $2-5 d$ \\
\hline & & & Eemian & $5 e$ \\
\hline \multirow{7}{*}{420} & \multirow{13}{*}{$\begin{array}{c}\text { Middle } \\
\text { Pleistocene }\end{array}$} & \multirow{6}{*}{$\begin{array}{l}\text { Middle } \\
\text { Polish }\end{array}$} & Odranian & 6 \\
\hline & & & Lublinian & 7 \\
\hline & & & Krznanian & 8 \\
\hline & & & Zbójnian & 9 \\
\hline & & & Liwiecian & 10 \\
\hline & & & Mazovian & 11 \\
\hline & & \multirow{11}{*}{$\begin{array}{l}\text { South } \\
\text { Polish }\end{array}$} & Sanian 2 & 12 \\
\hline \multirow{6}{*}{780} & & & & 13 \\
\hline & & & Ferdynandovian & 14 \\
\hline & & & & 15 \\
\hline & & & Sanian 1 & 16 \\
\hline & & & & 17 \\
\hline & & & & 18 \\
\hline \multirow[b]{4}{*}{900} & \multirow{4}{*}{$\begin{array}{l}\text { Lower } \\
\text { Pleistocene }\end{array}$} & & Podlasian & 19 \\
\hline & & & & 20 \\
\hline & & & & 21 \\
\hline & & & Nidianian & 22 \\
\hline
\end{tabular}

Fig. 2. Stratigraphic table of the Pleistocene glaciations in Poland (after Marks et al. 2016)

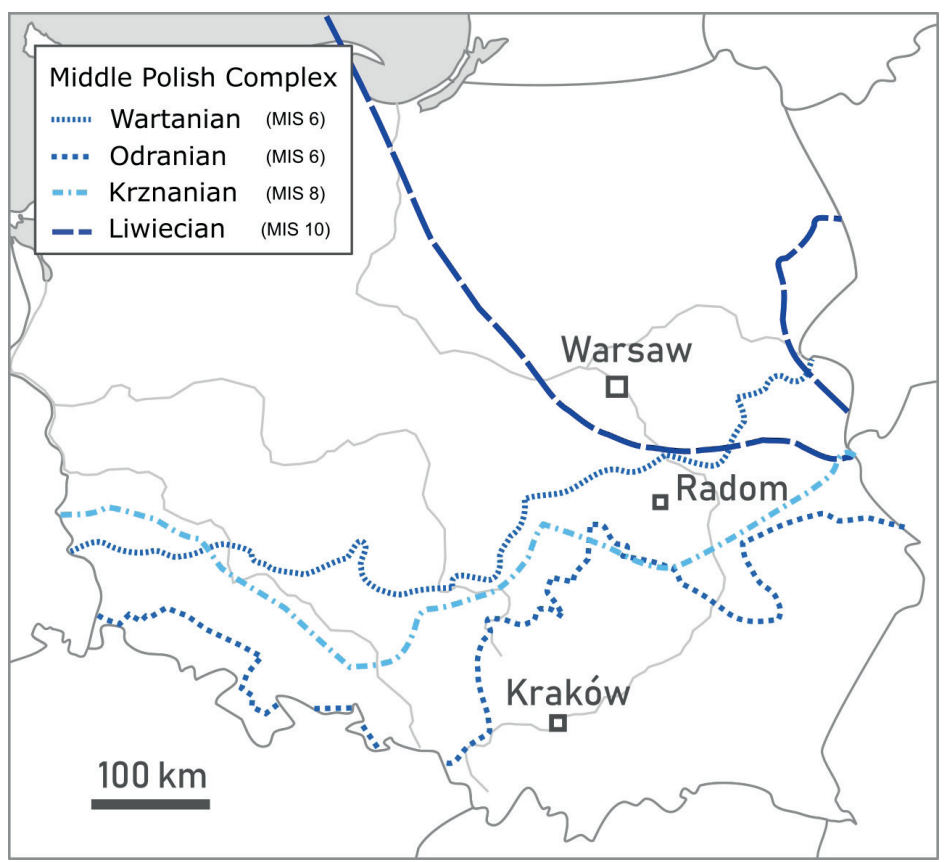

Fig. 3. Glaciation extents of Middle Polish Glaciation Complex in Poland (after Marks 2005, Marks et al. 2016) 


\section{MATERIAL AND METHODS}

The methods used in this study were adapted from Górska-Zabielska (2010 and references therein). The analysis was performed on the coarse pebble clasts of $20-60 \mathrm{~mm}$ in a major axis sampled from the till. Basic petrographic types were distinguished, as well as indicator and auxiliary erratics identified. The list of indictor erratics comprising 110 erratic types was adapted from Czubla (2001). To obtain statistically reliable results the indicator assemblage should consist of at least 40 specimens (cf. Smed 1993, Czubla 2001). The average amount of indicator erratics among the crystalline erratics is about $10 \%$; therefore, the analysis was carried out on a sample consisting of 500 clasts. The sample was collected from the outcrop of the till south of the city of Radom (Fig. 1). The sampling was performed in 2014 during road construction and carried excavations, which allowed access to the vertical profile of the geological strata. The collected erratics were identified on the basis of available atlases, both in the literature and on the internet (Czubla et al. 2006, Bräunlich 2018, Wilske 2018a, 2018b). The identification was performed under dry and wet conditions with the use of a magnifying glass. When needed, specimens were crushed to obtain a fresh surface or treated with hydrochloric acid. The results were presented on a circle map, showing the localities of erratic sources and amount of identified rocks (Smed 1993). For auxiliary erratics, a correction diminishing the role of the sedimentary rocks on the projected map was taken (Vinx et al. 1997, Czubla 2001). Theoretisches Geschiebezentrum (TGZ, Lüttig 1958), which constitutes the geographical point of the weighted average coordinates of assigned approximate indicator erratic sources was calculated regarding only indicator erratics.

\section{RESULTS}

The sampled till constitutes the first geological subsurface layer of the thickness of ca. $1 \mathrm{~m}$. The till is made of matrix-supported clast-poor diamicton of a light brown colour with well-rounded erratic clasts, which rarely exceed $10 \mathrm{~cm}$ in diameter. The till is underlain by light yellow, massive sand (Fig. 4). The contact of Quaternary strata with a Cretaceous basement was observed at a nearby site, $200 \mathrm{~m}$ to the north along the construction excavation. It is possible that the Quaternary sedimentary cover could have thickness of $<5 \mathrm{~m}$ at the sampling site.

The results of the petrographic composition show the largest contribution of crystalline rocks $-60.4 \%$, while carbonate and clastic sedimentary rocks content equals $18.4 \%$ and $15.0 \%$, respectively. Among the crystalline rocks, granites predominate, especially these with alkali feldspars. Subordinately, porphyries and metamorphic rocks are also present. Carbonates are mostly represented by grey (Palaeozoic) and white (Mesozoic) limestones.
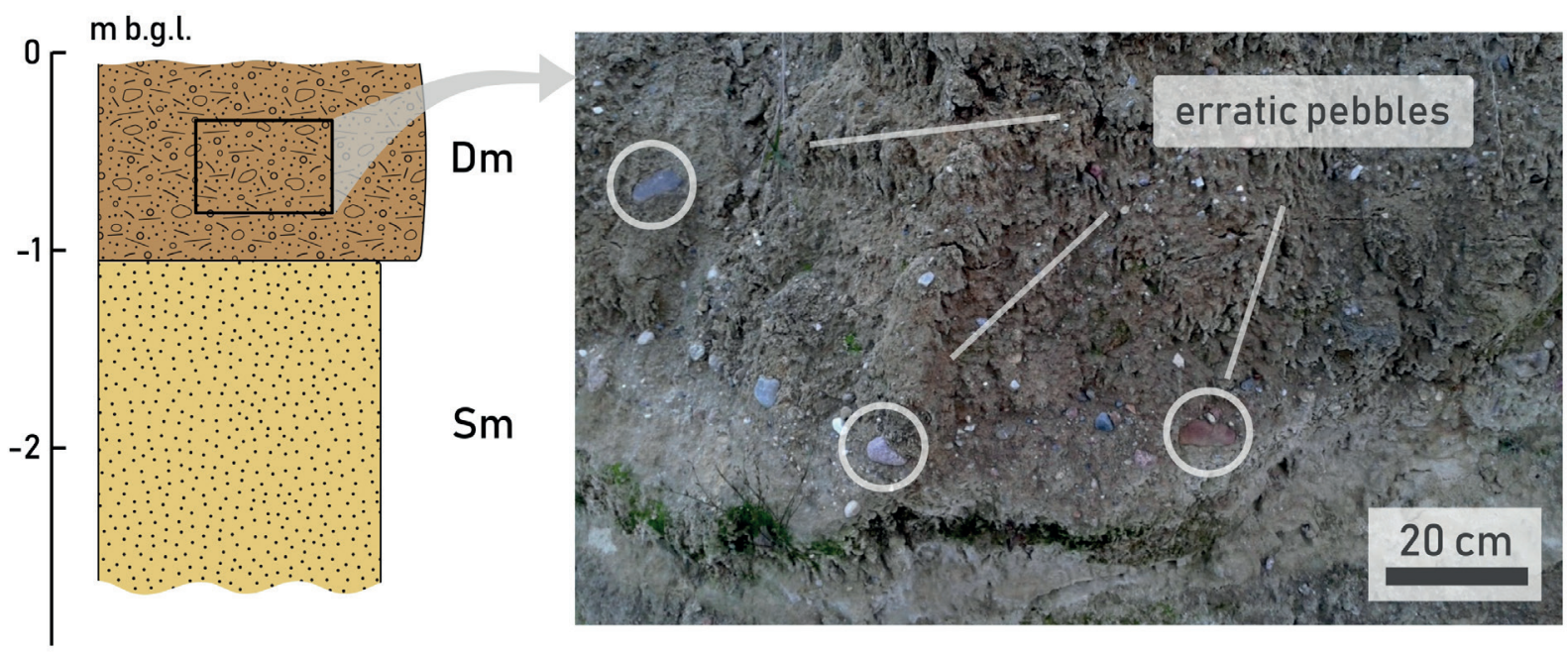

Fig. 4. The profile and the photo of the sampled outcrop: Dm - massive diamicton, Sm - massive sand 
Red limestones and dolomites are in the minority. Clastic sedimentary rocks are exclusively represented by sandstones. The rest of the petrographic types distinguished comprise trace amounts of the erratic assemblage and these are flints, quartz clasts and other rocks resembling local bedrocks (Tab. 1).

Table 1

Basic petrographic types of erratic pebbles; erratics list (after Górska-Zabielska 2010, modified)

\begin{tabular}{|l|c|c|}
\hline Petrographic type & Count & Amount [\%] \\
\hline Crystalline & 302 & 60.4 \\
\hline Grey limestone & 53 & 10.6 \\
\hline Red limestone & 1 & 0.2 \\
\hline White limestone & 33 & 6.6 \\
\hline Dolomite & 5 & 1.0 \\
\hline Sandstone & 75 & 15.0 \\
\hline Shale & 0 & 0.0 \\
\hline Flint & 15 & 3.0 \\
\hline Quartz & 3 & 0.6 \\
\hline Milky quartz & 6 & 1.2 \\
\hline Other local rocks & 7 & 1.4 \\
\hline
\end{tabular}

Indicator erratics constitute $14.2 \%$ of the crystalline rocks. The most numerous group is represented by pebbles from the Åland region and they comprise $62.8 \%$ of the indicator assemblage (Tab. 2). They are represented mainly by Åland rapakivi granite, Åland aplite granite and Åland granite, subordinately by Haga and Åland granite porphyry. Second significant group constitutes Baltic porphyries (11.7\%). Ångermanland and Uppland provenances have a contribution equal to $9.3 \%$. The Northern Baltic, Dalarna and Småland are represented by only single clasts (Fig. 5).

A numerous group of auxiliary erratics identified is comprised of Jotnian sandstones, however their origin area is widespread over the Fennoscandia Baltic Sea and covers areas such as Dalarna, northern and central Baltic Basin. The collected sandstones usually display advanced compaction and do not show any other distinctive features. The carbonates identified i.e. dolomites and grey limestones originated from central Baltic Sea, whereas white limestones derived from southern Baltic Basin and possibly northern Poland. Therefore, the part of white limestones can be also treated as local rocks. Consequently, local material (flints and other local rocks) range from $5 \%$ to $11 \%$ (including all white limestones).

The calculation of TGZ with regard to all of the listed crystalline indicator erratics yielded coordinates of $\varphi=60.1^{\circ} \mathrm{N}$ and $\lambda=19.5^{\circ} \mathrm{E}$. These coordinates point at the area localised within the Baltic Sea between Uppland and Åland regions.

Table 2

Results of the detailed identification of indicator and auxiliary erratic rocks, erratics list (after Czubla 2001)

\begin{tabular}{|l|l|c|c|}
\hline \multicolumn{1}{|c|}{ Provenance } & \multicolumn{1}{|c|}{ Indicator erratic } & Share [\%] & Count \\
\hline \multirow{2}{*}{ Ångermanland } & Ragunda granite & 2.3 & 1 \\
\cline { 2 - 4 } & Rödö granite and granite porphyry & 7.0 & 3 \\
\hline Northern Baltic & Bothnian porphyries & 2.3 & 1 \\
\hline \multirow{2}{*}{ Åland } & Åland granite, Haga granite, Aland rapakivi, Åland granite porphyry & 51.2 & 22 \\
\cline { 2 - 4 } & Åland aplite granite & 11.6 & 5 \\
\hline Dalarna & Bredvad porphyry & 2.3 & 1 \\
\hline Småland & Kinda granite & 2.3 & 1 \\
\hline \multirow{3}{*}{ Uppland } & Uppsala granite & 2.3 & 1 \\
\cline { 2 - 4 } & Sala granite & 2.3 & 1 \\
\cline { 2 - 4 } & Stockholm granite & 4.7 & 2 \\
\hline \multirow{2}{*}{ Central Baltic } & red Baltic quartz porphyry & 7.0 & 3 \\
\cline { 2 - 4 } & brown Baltic quartz porphyry & 4.7 & 2 \\
\hline Summary & & 100 & 43 \\
\hline Provenance & Auxiliary erratic & & Count \\
\hline \multirow{2}{*}{ Central Baltic } & dolomites & & 1 \\
\cline { 2 - 4 } & red Ordovician limestones & 21 \\
\hline Various & Jotnian sandstones & & 5 \\
\hline
\end{tabular}




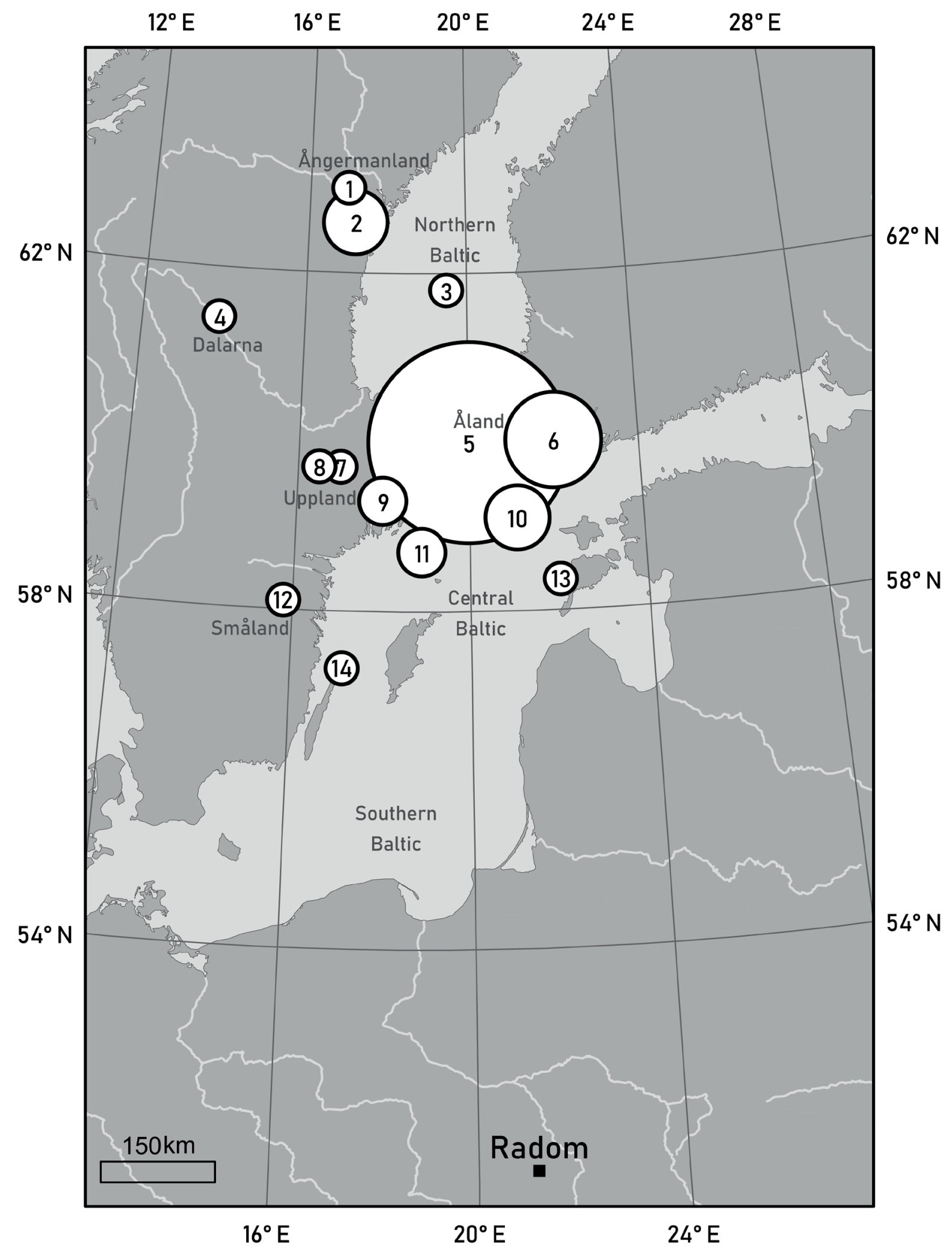

Fig. 5. Provenance of identified indicator erratics in the till. The circle's radius corresponds to the relative share: 1 - Ragunda granite and porphyry, 2 - Rödö granite and granite porphyry, Rödö quartz porphyry, 3 - Bothnian porphyries, 4 - Asen, Bredvad and Kåtilla porphyries, Garberg granite, 5 - Åland granite, Haga granite, Åland rapakivi, Åland granite porphyry, 6 - Åland aplite granite, 7 - Uppsala, Vänge, Arnö granites, 8 - Sala granite, 9 - Stockholm granite, 10 - red Baltic quartz porphyry, 11 - brown Baltic quartz porphyry, 12 - Kinda granite, 13 - dolomites, 14 - red Ordovician limestones; erratics list (after Czubla 2001) 


\section{DISCUSSION}

The stratigraphic position of the studied till based on indicator assemblage indicates an Odranian (MIS 6) origin. According to Czubla et al. (2017), the characteristic feature of MIS 6 glaciation in the record of erratic assemblages is a high contribution of Åland and Baltic indicator erratics, and small share of erratics from the southern and central-western Sweden. This pattern is well visible in the presented results. The TGZ position is comparable to these of Odranian/Wartanian glaciations (MIS 6) in central and eastern Poland as well (cf. Czubla 2015b) but it is shifted to the NE. Such a shift may be attributed to the high contribution of Åland erratics. However, the shift does not result from a significant contribution of western Finnish clasts, as recorded in eastern Poland (Gałązka 2004, Czubla 2015b). The analysed till constitute regional geological unit as well as is the first subsurface till unit in the area. The correlation of the till origin to the Odranian Glaciation is consistent with the age determined with thermoluminescence dating performed on the equivalent tills in adjacent area to the studied site (ca. $20 \mathrm{~km}$ to the west) by Kowalski \& Jaśkowski (1998). The age of the tills obtained by Kowalski \& Jaśkowski (1998) correspond to the Odranian Glaciation (MIS 6). However, the reliability of the thermoluminescence method for glacial sediments dating has recently been questioned (e.g. Fuchs \& Owen 2008). Nonetheless, silt underlying the till yielded an age corresponding to the Lublinian Interglacial (MIS 7), confirming the Odranian origin of the till.

Considering the spatial variability of the provenance of indicator erratics in the Odranian tills across Poland, the studied erratic assemblage shows an affinity for eastern Poland, rather than central Poland. Generally, a high contribution of Åland rocks is recorded in the Odranian tills across central and eastern Poland (Czubla 2001, Czubla et al. 2017). However, for eastern Poland a predominance of Åland erratics occurrence is characteristic, as they often constitute more than half of the indicator erratic assemblage. Therefore, the studied site is one of the most westward localised site with this affinity. Åland erratics are often considered to be easily recognizable due to their specific features. This can result in their slight overrepresentation in comparison to other erratics among the indicator assemblage. Nonetheless, in this case they constitute the leading sequence (cf. Górska 2006). Not only were several erratic types identified from the Åland region, but also adjacent areas are represented by noticeable amounts of erratics, thereby highlighting the importance of this region as the main source area.

Considering the contribution of other provenances, Ångermanland is represented above-average, but still within the shares found at other sites, especially those located east of the studied site, i.e. with eastern Poland affinity (Gałąka 2004, Czubla 2015b). It is worth mentioning that in the equivalent tills, several tens of kilometres to the north at the Warka site (cf. Czubla 2015b), a similar, minor number of erratics from the Småland region were recorded. Therefore, it is possible that, the zone of this latitude accounts for the minimum share of these rocks in Poland, whereas they are typical for Odranian/Wartanian tills in central Poland (Czubla 2001).

Considering the provenance of the sedimentary erratics, they are related to the southern and central Baltic Basin. Jotnian sandstones, which can derive from various regions, do not show any characteristic features allowing for their direct assignation to a specific region, e.g. Dalarna (cf. Smed 2010). However, most of them could possibly derive from Åland region and adjacent areas. The high contribution of other identified crystalline erratics argues for this provenance, indicative perhaps of the provenance of Jotnian sandstones (Meyer \& Lüttig 2007, Czubla 2015b).

The petrographic composition of the erratic pebbles indicates that the tills were affected by partial decalcification resulting from post-depositional chemical weathering due to the shallow burial of the till. It is mainly manifested in the relatively low amount of carbonate pebbles within the sample. Such a condition in tills can be encountered up to few meters under the surface (Woźniak et al. 2009). This can also explain elimination of dolomites and their present minor share. Nevertheless, examination of the decalcified tills still can give reliable results and allow for proper interpretation, especially regarding crystalline clasts (e.g. Czubla 2015a, Woźniak et al. 2009). 
No evidence was observed for the advance of mechanical weathering which could have influenced the results and their incorrect interpretation including TGZ position. Within the collected sample, clasts rich in biotite were well preserved, while additionally highly resistant clasts such as Bredvad porphyres were recorded only in trace amounts. This suggests that the recognition of the provenance was not disturbed and trace amounts of erratics recorded from several distant provenances to the provenance of the leading sequence highlights that these regions were not important source areas.

Spatial distribution of the identified provenances suggests that the incorporation of erratics occurred at a certain route of an advancing ice sheet. This route has its origin in northern Sweden (Ångermanland region) and extends through the northern Baltic, Åland region and adjacent areas to subsequently cover central and southern Baltic depression. It is almostlinear and oriented NNW-SSE. It seems that the studied till represents a record of the crystalline material incorporated almost entirely by an ice sheet following this route with the maximum incorporation from the central-eastern Fennoscandia.

\section{CONCLUSIONS}

This study supplements the results of recently realised studies on erratic pebbles in the glacial tills of Middle Polish Glaciation Complex in Poland. It covers a gap between the studies carried out in eastern and central Poland, and presents the first results on erratic pebbles provenance from the vicinity of the city of Radom. The results of the indicator erratic count method indicate an Odranian origin (MIS 6) for the tills and confirm the usefulness of the indicator erratic count method as a tool for till stratigraphy assessment. The indicator erratic assemblage shows a composition characteristic for the Odranian tills in eastern, rather than central Poland. The main source area was located within the Åland region and adjacent areas. Erratics from southern and central-western Sweden are almost entirely absent. The relatively low carbonate clast content indicates that the till was affected by partial decalcification resulting from post-depositional chemical weathering.
The author is grateful to P. Czubla and D. Nývlt for their valuable comments and suggestions on improvements to be made to the manuscript.

\section{REFERENCES}

Ber A., Lindner L. \& Marks L., 2007. Propozycja podziału stratygraficznego czwartorzędu Polski. Przegląd Geologiczny, 55, 115-118.

Bräunlich M., 2018. kristallin.de: Bräunlichs Geologieseite [on-line:] https://kristallin.de/ [access: 5.12.2014].

Czubla P., 2001. Eratyki fennoskandzkie w utworach czwartorzędowych Polski środkowej i ich znaczenie stratygraficzne. Acta Geographica Lodziensia, 80, 1-174.

Czubla P., 2015a. Analiza zespołów eratyków w glinach lodowcowych i ich znaczenie w rekonstrukcji zasięgu lądolodu warciańskiego w obszarze między Piotrkowem Trybunalskim, Radomskiem a Przedborzem. Acta Geographica Lodziensia, 103, 25-43.

Czubla P., 2015b. Eratyki fennoskandzkie w osadach glacjalnych Polski i ich znaczenie badawcze. Wydawnictwo Uniwersytetu Łódzkiego, Łódź.

Czubla P., Gałązka D. \& Górska M., 2006. Eratyki przewodnie w glinach morenowych Polski. Przeglad Geologiczny, 54, 352-362.

Czubla P. \& Mizerski W., 2003 Głazy narzutowe „Trojaczki" - nowo ustanowiony pomnik przyrody nieożywionej w Tarnowie. Przeglad Geologiczny, 51, 585-586.

Czubla P., Terpiłowski S., Orłowska A., Zieliński P., Zieliński T. \& Pidek I.A., 2017. Petrographic features of tills as a tool in solving stratigraphical and palaeogeographical problems - A case study from Central-Eastern Poland. Quaternary International [in press]. DOI: https://doi. org/10.1016/j.quaint.2017.08.028.

Fuchs M. \& Owen L.A., 2008. Luminescence dating of glacial and associated sediments: review, recommendations and future directions. Boreas, 37, 636-659.

Gałązka D., 2004. Zastosowanie makroskopowych badań eratyków do określenia stratygrafii glin lodowcowych środkowej i pótnocnej Polski. Uniwersytet Warszawski [Ph.D. thesis].

Górska M., 2006. Fennoscandian erratics in glacial deposits of the Polish Lowland - methodological aspects. Studia Quaternaria, 23, 11-15.

Górska-Zabielska M., 2008. Fennoskandzkie obszary alimentacyjne osadów akumulacji glacjalnej i glacjofluwialnej lobu Odry. Wydawnictwo Naukowe Uniwersytetu im. Adama Mickiewicza, Poznań.

Górska-Zabielska M., 2010. Analiza petrograficzna osadów glacjalnych - zarys problematyki. Landform Analysis, $12,49-70$.

Górska-Zabielska M., 2017. Erratic disappearances. Some remarks on their geotouristic values. Zeszyty Naukowe. Turystyka i Rekreacja, 2(20), 67-74.

Hanáček M. \& Nývlt D., 2009. Subglaciální štěrkovité tilly u Jindřichova na Osoblažsku. Časopis Slezského zemského muzea Opava (A), 58, 193-214.

Hesemann J., 1931. Das Glazialdiluvium Dänemarks, Hollands und Norddeutschlands vom geschiebekundlichen Standpunkt aus. Geologische Rundschau, 22(3-4), 145-155. 
Hesemann J., 1936. Zur Petrographie einiger nordischer kristalliner Leitgeschiebe. Abhandlungen der Preussischen Geologischen Landesanstalt, 173, Preussischen Geologischen Landesanstalt, Berlin.

Hesemann J., 1975. Kristalline Geschiebe dernordischen Vereisungen. Geologisches Landesamt Nordrhein-Westfalen.

Hoffmann K. \& Meyer K.-D., 1999. Indicator stone counts on Eisterian and Saalian sediments from eastern Germany. Geological Quarterly, 43(2), 233-240.

Jaśkowski B., Jurkiewicz H. \& Kowalski B., 1993. Szczegółowa mapa geologiczna Polski 1:50 000. Arkusz Radom (707). Państwowy Instytut Geologiczny, Warszawa.

Jaśkowski B., Jurkiewicz H. \& Kowalski B., 2014. Objaśnienia do szczegółowej mapy geologicznej Polski. Arkusz Radom (707). Państwowy Instytut Geologiczny, Warszawa.

Kondracki J., 1998. Geografia regionalna Polski. Wydawnictwo Naukowe PWN, Warszawa.

Korn J., 1927. Die wichtigste Leitgeschiebe der nordischen kristallinen Gesteine im norddeutschen Flachlande. Preussische Geologische Landesanstalt, Berlin.

Kowalski B.J. \& Jaśkowski B., 1998. Zasięg lądolodu zlodowacenia warty na obszarze między Grójcem a Szydłowcem $\mathrm{w}$ świetle datowań termoluminescencyjnych gliny zwałowej. Przeglad Geologiczny, 46, 355-358.

Lindner L., 2005. Nowe spojrzenie na liczbę, wiek i zasięgi zlodowaceń środkowopolskich w południowej części środkowowschodniej Polski. Przegląd Geologiczny, 53, 145-150.

Lüttig G., 1958. Methodische Fragen der Geschiebeforschung. Geologisches Jahrbuch, 75, 361-418.

Marks L., 2005. Pleistocene glacial limits in the territory of Poland. Przeglad Geologiczny, 53, 988-993.
Marks L., Dzieżek J., Janiszewski R., Kaczorowski J., Lindner L., Majecka A., Makos M., Szymanek M., Tołoczko-Pasek A. \& Woronko B., 2016. Quaternary stratigraphy and palaeogeography of Poland. Acta Geologica Polonica, 66, 403-427.

Meyer K.-D. \& Lüttig G., 2007. Was verstehen wir unter einem "Leitgeschiebe"? Geschiebekunde Aktuell, 23, $106-121$.

Milthers V., 1909. Scandinavian indicator-boulders in the Quaternary deposits: extension and distribution. Danmarks Geologiske Undersøgelse, Copenhagen.

Smed P., 1989. Sten i det danske landskab. Geografforlaget.

Smed P., 1993. Indicator studies: a critical review and a new data presentation method. Bulletin of the Geological Society of Denmark, 40, 332-340.

Smed P., 2010. Indicator count methods tested out on Møn, Denmark. Quaternary Science Journal, 59, 76-87.

Vinx R., Grube A. \& Grube F., 1997. Vergleichende Lithologie, Geschiebeführung und Geochemie eines Prä-Elster-I-Tills von Lieth bei Elmshorn. Leipziger Geowissenschaften, 5, 83-103.

Wilske H., 2018a. skan-kristallin [on-line:] https://skan-kristallin.de/ [access: 5.12.2014].

Wilske H., 2018b. StrandundSteine.de [on-line:] https:// strand-und-steine.de/ [access: 5.12.2014].

Woźniak P.P., Czubla P., Wysiecka G. \& Drapella M., 2009. Petrographic composition and directional properties of tills on the NW surroundings of the Gdańsk Bay, Northern Poland. Geologija, 51, 59-67.

Zandstra J.G., 1999. Platenatlas van noordelijke kristallijne gidsgesteenten. Backhuys Publishers (Leiden). 